\title{
PENINGKATAN KEMAMPUAN BERPIKIR KRITIS MELALUI MODEL PEMBELAJARAN BERBASIS MASALAH
}

\author{
Hidayatussakinah $^{1}$, Ismail Marzuki ${ }^{2}$, Nurul Alia Ulfa ${ }^{2}$ \\ ${ }^{1}$ Pendidikan Biologi FKIP UNIMUDA Sorong \\ ${ }^{2}$ Pendidikan Bahasa Indonesia FKIP UNIMUDA Sorong
}

sakinahunimuda@gmail.com

\begin{abstract}
ABSTRAK
Kemamampuan berpikir kritis merupakan kemamapuan yang harus dimiliki oleh peserta didik, dalam memecahkan masalah dalam pembelajaran. Penerapan model pembelajaran berbasis masalah dalam penelitian ini bertujuan untuk meningkatkan kemamapuan peserta didik dalam berpikir kritis. Jenis penelitian ini adalah kuantitatif-eksperimen semu dengan desain penelitain nonequivalent pretest posttest control group design. Jumlah Populasi dalam penelitian adalah 262 orang yang tergabung dalam kelas VII SMP Negri Mataram. Sampel penelitian berjumlah 114 orang yang terbagi menjadi 4 (Empat) kelas, diambil dengan menggunakan teknik sampling purposive. Instrumen yang digunakan untuk mengukur kemampuan berpiki kritis adalah tes essy. Data dianalisis menggunakan uji Anakova. Hasil penelitian menunjukkan bahwa kemampuan berpikir kritis dapat meningkat melalui penerapan model pembelajaran berbasis masalah.
\end{abstract}

Kata Kunci: Berpikir, Kritis dan Masalah.

\section{ABSTRACT}

Critical thinking skills are abilities that must be possessed by students, in solving problems in learning. The application of problem-based learning models in this study aims to improve students' ability to think critically. This type of research is a quasi-quantitative-quasi-experimental research design with nonequivalent pretest posttest control group design. The number of population in the study was 262 people who joined in class VII SMP Negri Mataram. The research sample consisted of 114 people divided into 4 (four) classes, taken using purposive sampling technique. The instrument used to measure critical thinking skills is the essy test. Data were analyzed using the Anacova test. The results showed that critical thinking skills can be increased through the application of problem-based learning models.

Keywords: Critical, Thinking, Problem.

\section{PENDAHULUAN}

Berpikir kritis merupakan kemampuan yang harus dimiliki oleh peserta didik dalam mata pelajaran IPA, karena sangat erat kaitannya dengan kehidupan seharihari, sehingga banyak masalah yang dapat disajikan dalam belajar guna mempermudah peserta didik dalam mencapai tujuan pembelajaran. Peserta didik dapat dikatakan memiliki kemampuan Berpikir kritis apabila mampu menganalisis fakta, menggeneralisasikan dan mengorganisasikan ide, mempertahankan opini, membuat perbandingan, menarik kesimpulan, menguji argumen, dan menyelesaikan masalah (1). Berpikir kritis juga dapat meningkatkan cara berpikir yang sistematis, kesadaran dalam berpikir, dan memiliki kemampuan untuk membedakan suatu kebenaran dari kesalahan (2). Proses berpikir secara kritis merupakan cara berpikir yang sangat komplek karena berpikir secara displin dan sistematis, proses berpikir kritis meliputi memberikan pendapat yang sesuai dengan fakta dan teori yang ada, menganalisis kemugkinan yang terjadi, memberi solusi untuk memecahkan masalah, menerapkan solusi, dan mengevaluasi hasil pemikiran serta menyimpulkannya (3). Kemampuan-kemampuan tersebut sangat menunjang peserta didik dalam belajar
IPA. indikator kemampuan berpikir kritis yang ingin dilihat pada penelitian ini adalah memberikan penjelasan sederhana (elemetary clarification), membangun keterampilan dasar (Basic support), membuat inferensi (infering), membuat penjelasan lebih lanjut (advanced clarification), Mengatur strategi dan taknik (strategies and tactic) (4).

Berdasarkan hasil observasi yang dilakukan dibeberapa sekolah, menunjukan bahwa kemampuan peserta didik dalam perpikir kritis masih rendah, hal tersebut ditunjukan melalui kegiatan pembelajaran masih berfokus pada guru dan kemampuan peserta didik masih didominasi pada ranah kognitif $\mathrm{C} 1$ dan $\mathrm{C} 2$, sedangkan kemampuan berpikir kritis menuntut peserta didik untuk menguasai seluruh ranah kognitif yaitu C1,C2,C3,C4,C5,C6.

Untuk meningkatkan kemampuan berpikir kritis peserta didik dalam pembelajaran IPA merupakan hal yang tidak mudah, sehingga guru harus membiasakan peserta didik dalam mencari dan memecahkan masalah pembelajaran sendiri, sehingga pembelajaran dapat didominasi oleh peserta didik. Salah satu cara membuat pembelajaran berpusat pada peserta didik sehingga dapat meningkatkan kemampuan berpikir kritis, salah satunya adalah 
dengan menerapkan model pembelajaran berbasis masalah.

Model pembelajaran berbasis masalah adalah pembelajaran yang dirancang berdasarkan masalah nyata (rill) dalam kehidupan, sehingga dapat meningkatkan pemahaman peserta didik terhadap materi yang dipelajari, kemampuan memecahkan masalah dan keterampilan menerapkan konsep sehingga dapat melatih berpikir tingkat tinggi peserta didik (5). Penerapan model pembelajaran berbasis masalah dalam pembelajaran melalui lima fase yaitu: (a) Memberikan orientasi tentang permasalahannya kepada peserta didik (Pendidik membahas tujuan pelajaran, mendiskripsikan dan memotivasi peserta didik untuk terlibat dalam kegiatan mengatasi masalah), (b) Mengorganisasikan peserta didik untuk meneliti (Pendidik membantu peserta didik untuk mendefinisikan dan mengorganisasikan tugas-tugas belajar terkait dengan permasalahannya), (c) Membantu investigasi mandiri dan kelompok (Pendidik mendorong peserta didik untuk mendapat informasi yang tepat, melaksanakan ekperimen, mencari penjelasan dan solusi), (d) Mengembangkan dan mempersentasikan hasil (Pendidik membantu peserta didik dalam merencanakan dan menyiapkan hasil-hasil yang tepat, seperti laporan, rekaman video, dan model-model dan membantu mereka untuk menyampaikan kepada orang lain) dan (e) Menganalisis dan mengevaluasi proses mengatasi masalah (Pendidik membantu peserta didik untuk melakukan refleksi terhadap investigasinya dan proses-proses yang mereka gunakan) (6).

Berdasarkan pengertian dan fase-fase model pembelajaran berbasis masalah diatas dapat dijadikan sebagai tolak ukur keberhasilan penerapannya dalam meningkatkan keaktifan dan kemampuan berpikir kritis peserta didik jika laksanakan secara prosedural. Salah satu Karaktristik yang dimiliki oleh model pembelajaran berbasis masalah ini adalah menantang peserta didik berpikir secara sistematis untuk memecahkan masalah (7), oleh karena itu model pembelajaran ini sangat efektif diterapkan dalam materi pembelajaran IPA.

Penelitian yang relevan terkait penerapan model pembelajaran berbasis masalah dalam meningkatkan kemampuan berpikir kritis peserta didik banyak diungkapakn oleh peneliti dengan hasil penelitian sebagai berikut: mengatakan bahwa Kemampuan berpikir kritis dapat dikembangkan melalui penerapan model pembelajaran berbasis masalah (8), model pembelajaran berbasis masalah dan keterampilan berpikir kritis siswa berpengaruh positif terhadap literasi lingkungan peserta didik (9), model pembelajaran berbasis masalah dapat meningkatkan kinerja dan kemampuan berpikir kritis peserta didik pada materi system ekskresi (10).

Hasil penelitian diatas dapat dijadikan sebagai referensi penerapan model pembelajaran berbasis masalah dalam penelitian ini yang bertujuan untuk meningkatkan kemampuan berpikir kritis peserta didik.

\section{METODE PENELITIAN}

Penelitian ini termasuk jenis penelitian kuantitatif-eksperimen dengan desain quasi exsperimen yang bertujuan untuk mencari pengaruh perlakuan tertentu terhadap variabel-variabel yang diteliti. Bentuk desain quasi eksperimen yang digunakan adalah pretest postest kontrol group design dengan rancangan faktorial $2 \times 2$. Populasi yang digunakan dalam penelitian ini adalah semua peserta didik kelas VII SMP Negeri 3 Mataram yang berjumlah 262 peserta didik. Sedangkan sampel berjumlah 114 peserta didik yang diambil dengan tehnik Purposive Sampling. Instrumen penelitian yang digunakan adalah soal essay. Analisis data diawali dengan uji normalitas dan uji homogenitas dan dilanjutkan dengan uji hipotesis menggunakan uji Anakova dengan bantuan SPSS versi 22. Untuk mengetahui peningkatan nilai rata-rata peserta didik pada saat pretest dan posttest, dilakukan analisis uji $\mathrm{N}$ gain terhadap kemampuan berpikir kritis dengan menggunakan persamaan:

$$
N \text {-gain }(\%)=\frac{\text { nilai postest-nilai pretest }}{\text { nilai maksimum-niali pretest }} \times 100 \%
$$

\section{HASIL DAN PEMBAHASAN}

Data Hasil penelitian terlebih dahulu dilakukan uji normalitas dan uji homogenitas dengan bantuan program SPSS versi 22. Hasil Uji normalitas menggunakan uji kolomogorof smirnov menyatakan bahwa data terdistribusi secara normal $(0.166>0.05)$, sedangkan uji homogenitas menggunakan levene's test menyatakan bahwa data tersebar secara homogen $(0.188>0.05)$. pada penelitian ini, selain dilakukan uji hipotesis menggunakan uji anakova dan uji $N$ Gain, juga dilakukan pengukuran pada masing-masing indikator kemampuan berpikir kritis. berdasarkan pengukuran tersebut ditemukan bahwa rata-rata indikator mengalami peningkatan, berikut tabel 1.1 yang menyatakan hasil pengukuran indikator kemampuan berpikir kritis:

Tabel 3.1 hasil pengukuran indikator kemampuan berpikir kritis

\begin{tabular}{|c|c|c|c|}
\hline No & Indikator KBK & $\begin{array}{l}\text { Nilai } \\
\text { sebelum } \\
\text { penerapan } \\
\text { PBM }\end{array}$ & $\begin{array}{l}\text { Nilai } \\
\text { sesudah } \\
\text { penerapan } \\
\text { PBM }\end{array}$ \\
\hline 1 & $\begin{array}{l}\text { Memberikan } \\
\text { penjelasan sederhana } \\
\text { (elemetary } \\
\text { clarification) }\end{array}$ & 3.0 & 3.2 \\
\hline 2 & $\begin{array}{l}\text { membangun } \\
\text { keterampilan dasar } \\
\text { (Basic support),), }\end{array}$ & 2.8 & 3.4 \\
\hline 3 & $\begin{array}{l}\text { (c) membuat } \\
\text { inferensi (infering), }\end{array}$ & 2.7 & 3.4 \\
\hline 4 & $\begin{array}{lr}\text { d) } & \text { membuat } \\
\text { penjelasan } & \text { lebih } \\
\text { lanjut } & \text { (advanced }\end{array}$ & 2.7 & 2.8 \\
\hline
\end{tabular}




\begin{tabular}{|l|l|l|l|}
\hline & clarification & & \\
\hline 5 & $\begin{array}{l}\text { e) Mengatur strategi } \\
\text { dan taknik (strategies } \\
\text { and tactic). }\end{array}$ & 2.5 & 2.8 \\
\hline
\end{tabular}

Berdasarkan tabel diatas menunjukan bahwa indikator yang mengalami peningkatan paling signifikan adalah indikator yang ketiga yaitu membuat inferensi (infering). Peningkatan kemampuan berpikir kritis pada setiap indikator dapat disebabkan oleh beberapa faktor diantaranya (a) peranan guru, yang meliputi: pertanyaan yang di berikan guru dapat memancing siswa untuk bertanya maupun berpendapat, guru mampu menyajikan materi pembelajaran dengan mudah dan menyenangkan sehingga peserta didik merasa dapat memahami materi pelajaran dengan mudah, guru aktif mengkonfirmasi semua peserta didik, (b) peranan siswa, peserta didik terlihat termotivasi dan antusias dalam belajar, berani mengungkapkan pendapatnya dan melontarkan pertanyaan.

Selain dari faktor diatas, ada beberapa faktor yang dikemukaan oleh para ahli tentang peningkatan kemampuan berpikir krits diantaranya: Kondisi fisik, apabila kondisi fisik peserta didik tergangu, maka akan berpengaruh pada kemampuan berpikir yang di tandai dengan menurunya konsentrasi dan semangat belajar berkurang (11), Motivasi, dengan memotivasi peserta didik, guru dapat dengan mudah menyampaikan bahan pembelajaran dan mencapai tujuan pembelajaran karena minat peserta didik sudah tumbuh, Kecemasan, reaksi terhadap kecemasan dapat bersifat konstruktif yaitu memotivasi individu untuk belajar dan mengadakan perubahan terutama perubahan perasaan tidak nyaman, serta terfokus pada kelangsungan hidup dan destruktif (menimbulkan tingkah laku maladaptif dan disfungsi yaitu menyangkut kecemasan berat atau panik serta dapat membatasi seseorang dalam berpikir (12), Perkembangan intelektual, peserta didik memiliki tingkat perkembangan intelektual berbeda-beda, hal tersebut dapat disebabkan karena faktor usia. semakin bertambah umur anak, semakin tampak jelas kecenderungan dalam kematangan proses (13), Interaksi, salah satu faktor yang dapat mempengaruhi perkembangan kemampuan berpikir kritis adalah interaksi antara pengajar dan peserta didik (14). Suasana pembelajaran yang kondusif akan meningkatkan semangat siswa dalam proses pembelajaran sehingga siswa dapat berkonsentrasi dalam memecahkan masalah yang diberikan.

Faktor-faktor yang mempengaruhi peningkatan kemampuan berpikir kritis diatas menjadi salah satu penguat Hasil uji $N$-Gain yang dilakukan untuk melihat peningkatan nilai rata-rata pada kelas ekperimen dan kelas kontol, hasil tersebut menunjukan bahwa nilai $N$-Gain pada kelas eksperimen lebih tinggi jika dibandingkan dengan kelas kontrol yaitu 36\% di kelas eksperimen dan $9 \%$ di kelas kontrol.
Uji hipotesis yang bertujuan untuk melihat peningkatan variable $X$ terhadap variable $Y$ dilakukan menggunakan uji anakova dengan hasil menunjukan bahwa nilai signifikansi lebih kecil dari nilai alpa $(\alpha)$ yaitu $(0.00>0.05)$ (Tabel 1.2), berdasarkan hasil uji anakova tersebut dapat disimpulkan bahwa model pembelajaran berbasis masalah dapat meningkatkan kemampuan berpikir kritis peserta didik.

Table 3.2 Hasil Uji Anakova Model PBM Terhadap KBK

\begin{tabular}{|l|c|c|c|c|c|}
\hline & $\begin{array}{c}\text { Type } \\
\text { III Sum } \\
\text { of } \\
\text { Square } \\
\text { S }\end{array}$ & df & $\begin{array}{c}\text { Mean } \\
\text { Square }\end{array}$ & F & Sig. \\
\hline Source & $\begin{array}{c}\text { Sig } \\
\text { Model PBM } \\
\text { terhadap KBK }\end{array}$ & 521.455 & 1 & 521.455 & $\begin{array}{r}39.13 \\
.000\end{array}$ \\
\hline
\end{tabular}

Keberhasilan model pembelajaran berbasis masalah dalam meningkatkan kemampuan berpikir kritis peserta didik tidak terlepas dari kelebihankelebihan yang dimiliki olehmodel pembelajaran berbasis masalah diantaranya: pembelajaran berpusat pada peserta didik, dapat melatih peserta didik dalam pola pemecahan masalah, dalam proses pemecahan masalah peserta didik dilibatkan secara langsung untuk mempresentasikan hasil pemecahan masalahnya sehingga dapat melatih peserta didik berbicara sendiri dihadapan orang banyak, peserta didik diajarkan menjadi penyelidik yang aktif (15), peserta didik menjadi lebih ingat dan meningkat pemahamnya atas materi ajar, meningkatkan fokus pada pengetahuan yang relevan, mendorong untuk berfikir, membangun kerja tim, kepemimpinan, dan keterampilan sosial, membangun kecapan belajar dan memotivasi peserta didik (16).

\section{KESIMPULAN}

Berdasarkan hasil penelitian dan pembahasan diatas, dapat disimpulkan bahwa model pembelajaran berbasis masalah dapat meningkatkan kemampuan berpikir kritis peserta didik

\section{DAFTAR PUSTAKA}

1. Chance, P. Thinking in The Classroom: A survey of Programs. New York: Teachers College, Columbia University. 1986.

2. Resiman. Meningkatkan Kemampuan Berpikir Kritis Melalui Pembelajaran Matematika Dengan Pendekatan Matematika Realistik. IKIP PGRI Semarang. 2013.

3. Scriven, M., Paul. R. 1987. [online] : http://www.criticalthinking.org/aboutCT /define_crtitical thinking.ctm. [Cited: September 2020].

4. Ennis, R. H. Goal For A Critical Thinking I Curiculum .Developing Minds A Resource Book For Techin Thinking. Virginia: assocation for superpision and curiculum development (ASCD). 1985.

5. Wijaya, I . W., Lasmawan, I. W., Suastra, I. W. Pengaruh Model Pembelajaran Berbasis Masalah 
Terhadap Hasil Belajar IPA Ditinjau Dari Minat Siswa Terhadap Pelajaran IPA Pada Siswa SD Di Gugus IV Kecamatan Manggis. e-Journal Program Pascasarjana Universitas Pendidikan Ganesha Program Studi Pendidikan Dasar: 2015.

6. Sugiyanto. Model Model Pembelajaran Inovatif. Surakarta: Yuma Pustaka. 2012.

7. Joko, T., Ahdinirwanto, R. W., Maftukhin, A. Peningkatan Kemampuan Berpikir Kritis Melalui Model Pembelajaran Children Learning In Science (CLIS) pada Siswa Kelas VIII SMP Negeri 1 Mirit Tahun Pelajaran 2012/2013. Universitas Muhammadiyah Purworejo. 2013

8. Nuswowati, M., Susilaningsih, E., Ramlawati, \& Kadarwati, S. 2012. Implementation Of ProblemBased Learning With Green Chemistry Vision To Improve Creative Thinking Skill And Students' Creative Actions. Jurnal Pendidikan IPA Indonesia. 2017.

9. Suhirman. Hubungan Pembelajaran Berbasis Masalah Dengan Keterampilan Berpikir Kritis Dan Literasi Lingkungan Siswa. Jurnal dan Pendidikan Ilmu Sosial. 2020.

10. Lestari, D. D., Ansori1, I., Karyadi1, B. Penerapan model pbm untuk meningkatkan kinerja dan kemampuan berpikir kritis siswa SMA. Jurnal Pendidikan dan Pembelajaran Biologi 2017.

11. Sajoto, M., Peningkatan \& Pembinaan Kekuatan Kondisi Fisik Dalam Olahraga. Jakarta: Dahara Prize. 1990

12. Prameswari, S.W., Suharno., Sarwanto. Inculcate Critical Thinking Skills In Primary Schools. 1 st National Seminar on Elementary Education. SHEs: Conference Series 1. 2018.

13. Purwanto, N. Psikologi Pendidikan. Bandung: Remaja Rosdakarya Offset. 1992.

14. Himawan, I. Kontribusi Persepsi Tentang Pemanfaatan Media Pembelajaran dan Kemampuan Berpikir Kritis Terhadap Prestasi Belajar Sejarah Siswa Kelas X di SMA Negeri 1 Ngemplak Boyolali Tahun Ajaran 2012/2013. 2014.

15. Arends, R. I. Learning To Teach: Belajar Untuk Mengajar. 2008.

16. Amir, T. Inovasi Pendidikan Melalui Problem Based Learning. Jakarta. Kencana: Prenada Group. 2015. 